TECHNICAL TRANSACTIONS 4/2018

ARCHITECTURE AND URBAN PLANNING

DOI: $10.4467 / 2353737$ XCT.18.050.8362

Rafał Blazy (rafal.blazy@pk.edu.pl)

Laboratory of Downtown Areas Design, Faculty of Architecture, Cracow University of Technology

\title{
CONCEPTS OF TRANSFORMATIONS OF CITIES - EXAMPLES FROM THE Silesian AgGLOMERATION
}

\author{
IDEE PRZEKSZTAECANIA MIAST \\ - PRZYKŁADY Z AgLOMERACjI ŚląSKIEJ
}

\begin{abstract}
The problem of functional, compositional, and structural transformations, necessary to be introduced in contemporary inner cities, is complex and multithreaded. Sometimes cities get compared to palimpsests - re-used parchments from which old texts were removed in order to replace them with new ones. Undoubtedly, they are very particular palimpsests, as it is very difficult to clearly assess what should be protected and preserved, and what can be replaced or reconstructed. This paper discusses problems and concepts of transformations of selected city centres of the Silesian agglomeration, paying special attention to big comprehensive reconstructions of Katowice and Gliwice.
\end{abstract}

Keywords: Theory of urban design, concepts of reconstruction of cities, reconstruction of Silesian cities, reconstruction of Katowice, reconstruction of Gliwice, city centre revitalisation, future of cities, city forming

\section{Streszczenie}

Problem przekształceń funkcjonalnych, kompozycyjnych i strukturalnych, koniecznych do wprowadzenia we współczesnych śródmieściach, jest złożony i wielowątkowy. Miasta czasami porównuje się z palimpsestami, czyli pergaminami, z których, chcąc wykorzystać cenny podkład, usuwano dawne zapisy, aby je zastąpić nową treścią. Są one niewątpliwie palimpsestami szczególnymi, gdyż bardzo trudno jest jednoznacznie ocenić, co powinno podlegać ochronie i pozostawieniu, a co można zastąpić względnie przebudować. Artykuł omawia problemy i idee przekształcenia wybranych centrów miast aglomeracji śląskiej, zwracając szczególną uwagę na duże - kompleksowe przebudowy Katowic i Gliwic.

Słowa kluczowe: teoria projektowania miast, idee przebudowy miast, przebudowa miast śląskich, przebudowa Katowic, przebudowa Gliwic, rewitalizacja centrum, przyszłość miast, formowanie miasta 


\section{Introduction}

Cornelis van Eesteren, a great theoretician and experienced urban planner, said years ago: "(...) cities can be neither better nor more orderly than societies which created them. This fact will be changed neither by the urban planner's knowledge nor his personal views. The city is as if a projection of the society, each city map constitutes a deposit left by a certain social system" [2, p. 33]. Therefore, what is the projection of the contemporary Polish society? There is no doubt it has been much divided and stratified, especially in recent times, and these properties are definitely discernible in towns and cities of today. In this respect, one of the most visible divisions in Polish towns and cities is the dissonance between the city centre and the inner city, or downtown area. This diversification is primarily based on functional differences occurring in these areas. Functional changes entail also changes in the form of the urban tissue and changes in the standards and quality of architecture. The second clear division is marked between the inner city and suburban residential areas, shaped by individual buildings. These zones are separated by an irregular and very enigmatic borderline, dividing - as it were - two different worlds.

It must be acknowledged after Barbara Bartkowicz that "(...) 45 years of socialist economy and the contemporary process of political transformation created mixed structures, incoherent in functional and spatial terms, with a lot of wasted areas. A significant property of Polish towns and cities is the blurring of the border of urban investment lands, evolving into chaotically urbanised rural areas" $[4, \mathrm{p} .14] .^{1}$

"The degradation factor [... of these areas] is the growing spatial chaos, intensifying particularly in the last fifteen years of the political transformation, caused by uncoordinated investment activities nearly in all areas, even the ones subjected to legal protection. This refers to in particular:

- Chaotic road envelopes and the growing dispersion of development around towns and cities in rural areas,

- Location of large commercial structures within the areas of municipal greenery and in historic industrial complexes, as well as inside or around small towns.

- Destruction of greenery and substance around modernised traffic routes and interchanges (also multilevel ones) built within urban tissue, which do not solve any problems anyway, additionally contributing to the disintegration of the space, and essentially still introduce traffic into narrow city streets" [3, pp. 29-30].

In Silesia, many areas which are now located in the very centres of towns and cities, in the $19^{\text {th }}$ and $20^{\text {th }}$ century were used for industrial and warehousing purposes; furthermore, many city centres fell into decay, and sometimes were even devastated and degraded. The issue of their transformation constitutes a fundamental and strategic problem of reconstruction of towns and cities and of shaping of a new appearance of these organisms. In many cases it refers

In the text cited Barbara Bartkowicz also observed as follows: "Such a role cannot be usually played by existing Studies (...), diversified in terms of their contents and character. Existing local development plans, drawn up selectively for small areas, will likewise prove to be of little use". 
to the search of a new identity of cities, as well as to the creation of their new image. In this respect some cities try to outline and obtain a new image by means of subsequent investments. ${ }^{2}$

\section{Situation of silesian towns and cities}

Sometimes cities get compared to palimpsests - re-used parchments from which old texts were removed in order to replace them with new ones. Undoubtedly, they are very particular palimpsests, as it is very difficult to clearly assess what should be protected and preserved, and what can be replaced or reconstructed. Quite extensive contemporary comprehensive reconstructions of city centres in Katowice and Gliwice deserve special attention in this respect. In these territories the reconstruction of the road system constituted a key element of transformations of big parts of inner cities.

Katowice, the capital of Silesian Metropolis, has been modernised very dynamically and intensively in recent years. After over 6 years, in April 2017 the reconstruction along the line between the Market Square and the Roundabout was completed. This project cost over PLN 263 million, and it linked a part of the Old Town with the so-called Culture Zone, built in the vicinity of Spodek. This zone comprises the following entertainment and culture facilities: International Congress Centre, a new seat of the Polish National Radio Symphony Orchestra, and the new Silesian Museum. These facilities cost over PLN 1 billion. An investment that is in progress at the moment is two new office buildings near Spodek, erected in the area formerly occupied by the demolished DOKP tower in Katowice. These facilities are erected under the name of KTW (KTW is an abridged name of Katowice, used on plane tickets). At the same time, they constitute a very important element of the compositional project of Chorzowska street, along which such projects as Silesia City Center in Katowice and Silesia Business Park have been implemented. The route of this street was reconstructed and put into use in its new form in 2006, when a 657-metre-long tunnel was opened underneath Generała Ziętka Roundabout, and the roundabout itself was covered with a state-of-the-art dome $\left(1200 \mathrm{~m}^{2}\right)$, which hovers above a half of the platform of the roundabout. Thanks to the revitalisation of post-mining zones and owing to other investments implemented in the city centre, Katowice has experienced an enormous change and it has stopped being a city exclusively associated with heavy industry; undoubtedly, today it aspires to the title of the capital of the metropolis (Fig. 1).

Along with an attempt to be granted the title of the European Capital of Culture, an idea was conceived in Katowice to promote it as the City of Gardens. This motto relates to creating a specific image of the city in connection with specific spatial changes. It entails the municipal authorities' need to invest in gardens and to improve their quality. Green

2 To a certain extent a city which is firmly founded on historic industrial structures is Zabrze. Many revitalisation processes in this city are focused on the creation of post-industrial heritage. Examples in this respect could be revitalisation projects of the Guido mine and elevator shaft top, "Queen Luiza" Mining Heritage Park, industrial elements introduced in Pieruszki square (formerly Wincenty Pstrowski square), construction of a playground in the form of a mine, the so-called Bajtel Gruba (Silesian: children's mine). Similar actions are undertaken in the nearby Ruda Śląska, with "Ficinus” workers' colony amongst structures revitalised recently. 
elements are to play a decisive role in new and currently revitalised public spaces. The effect of promoting Katowice as the City of Gardens is the fact that more and more tourists, hearing that Katowice is a city of gardens, start to actively look for and visit public spaces in Katowice, which contributes to their popularity. Such a declaration made by the municipal authorities is also a certain commitment - more and more funds get allocated to the revitalisation of green and public areas in Katowice.

In 2015 the first speed limit zone was introduced in Katowice, with the permissible speed of $30 \mathrm{~km} / \mathrm{h}$. The 30 speed zone in Katowice aims to improve safety and to facilitate pedestrian and cycling traffic in the districts of Tysiąclecia Housing Estate and Ochojec. According to the municipal authorities' argumentation, the goal in this respect is to improve the attractiveness of the city and of living in it, as well as obtaining better safety standards.

The contemporary lack of spatial homogeneity in Katowice partly results from historical reasons, as well as from the spatial policy implemented in the last 70 years. Katowice is 150 years old, its structure consists of historical villages, colonies, and hamlets, along with the $19^{\text {th }}$-century block development intertwined between them and numerous random modernist projects. The space of Katowice is very heterogenous, one could even describe it as a mosaic. A study carried out in the second half of the 1970s by Bohdan Jałowiecki, focusing on the centre of Katowice, identified this place in the eyes of its residents as an area of occasional shopping and areat transport hub [7, pp. 162-167].

On the other hand, a study carried out by Tomasz Nawrocki in 2004 focusing on the perception of the central space of Katowice further confirmed very strong negative associations and connotations of this place. For $47 \%$ of respondents this space was significant exclusively as a transport hub, for $36 \%$ as a place of shopping, and $23 \%$ perceived only the administrative significance of the centre. Characteristically enough, $21 \%$ of respondents did not register any important and characteristic functions fulfilled by the centre, or claimed that Katowice was deprived of any centre whatsoever [11, pp. 255-260]. It has to be acknowledged, however, that the aforementioned new investments in the centre of Katowice still only complete a certain patchwork structure. This structure is very heterogenous, fragmentary, limited to demarcated areas of investments (Fig. 1 and Fig. 4). ${ }^{3}$

Gliwice has been undergoing significant transformations, as well. Only in the very heart of the city, near the railway station, a big transport hub is planned. It is to serve as a new city centre of some sort, located at the end of Zwycięstwa street, and commencing on the historic Market Square. The entire project is to consume PLN 125 million and it is to be completed by the end of 2020. Very important investments in Gliwice are the 'Podium' Hall and the recently completed reconstruction of the Cross-Regional Highway. The thorough change of the traffic system, caused by the introduction of the Cross-Regional highway in the centre of Gliwice, changed the way this part of the city functioned. Spaces which used to be linked,

If one wishes to build spatial relations, one should build urban tissue creating broader spatial interrelations. They could come into being by means of convergence of composition and combination of elements of the structure. Creation of references and a grid of relations between points, lines, areas (fields) located within the perimeter of the city (may) constitute a matrix for consolidation of the urban tissue. Proximity of individual fragments and urban complexes stimulates and generates helpful solutions of individual components of the city architectonics. 


\section{Katowice - Centre $\quad 0=0.20 .050 .7 .75 \mathrm{~km}$}

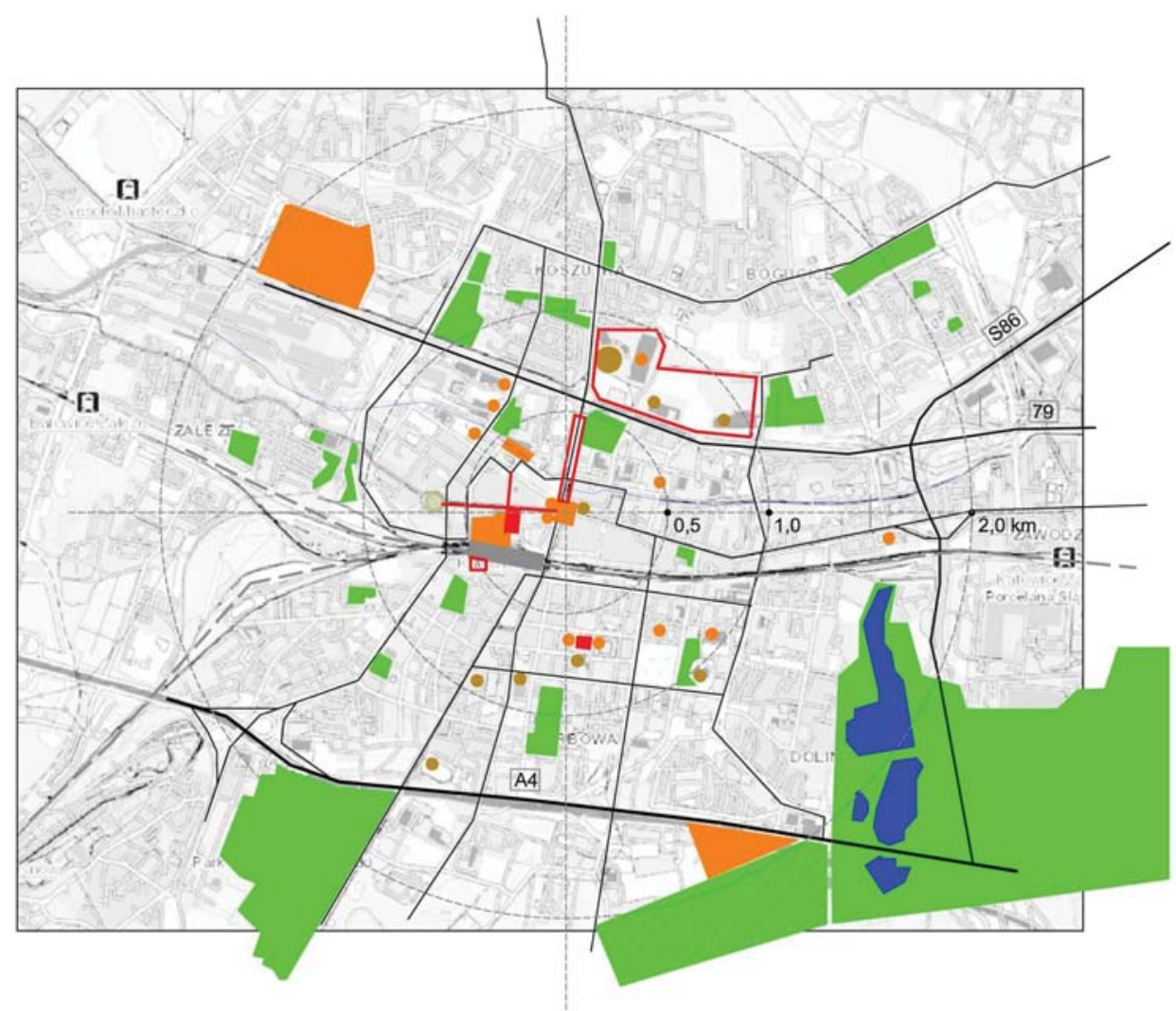

LEGEND:
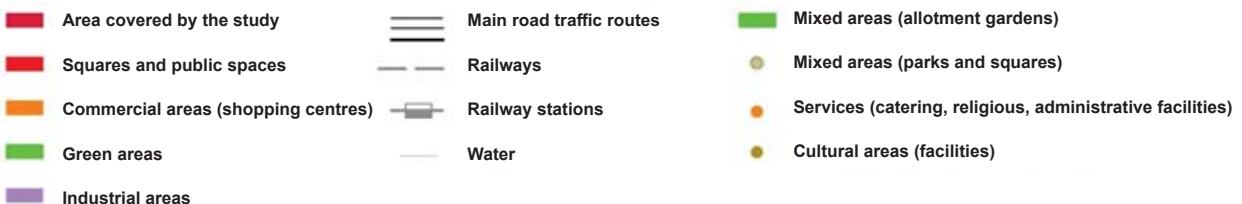

Fig. 1. Functional layout of Katowice with areas of revitalisation carried out in recent years (prepared by R. Blazy)

got separated and fragmented. In the places of former spatial barriers new - sometimes quite accidental - links and consolidations came into being, some buildings got uncovered, and some of them hidden behind acoustic screens. Smaller fragments of the urban tissue changed their mode of operation completely, at the same time changing their physiognomy, aesthetics, and principles of composition. This brought about a deep and quite unexpected transformation of the spatial and functional structure of the inner city. 
Both city centres referred to above share one feature - they are intersected with new roads, built in locations which had been developed and urbanised before, sometimes in the places of old parks, historic factories, or tenement houses. The Cross-Regional Highway in Gliwice is said to "have gashed" the city centre (Fig. 2). The Cross-Regional Highway in Gliwice is perceived as a scar in the urban tissue. In historical terms, the centre of Chorzów has a similar experience - in 1979 a trestle bridge was built, intended for car traffic from Katowice to Bytom. This way Chorzów lost its historic Market Square, and today over 30 thousand cars
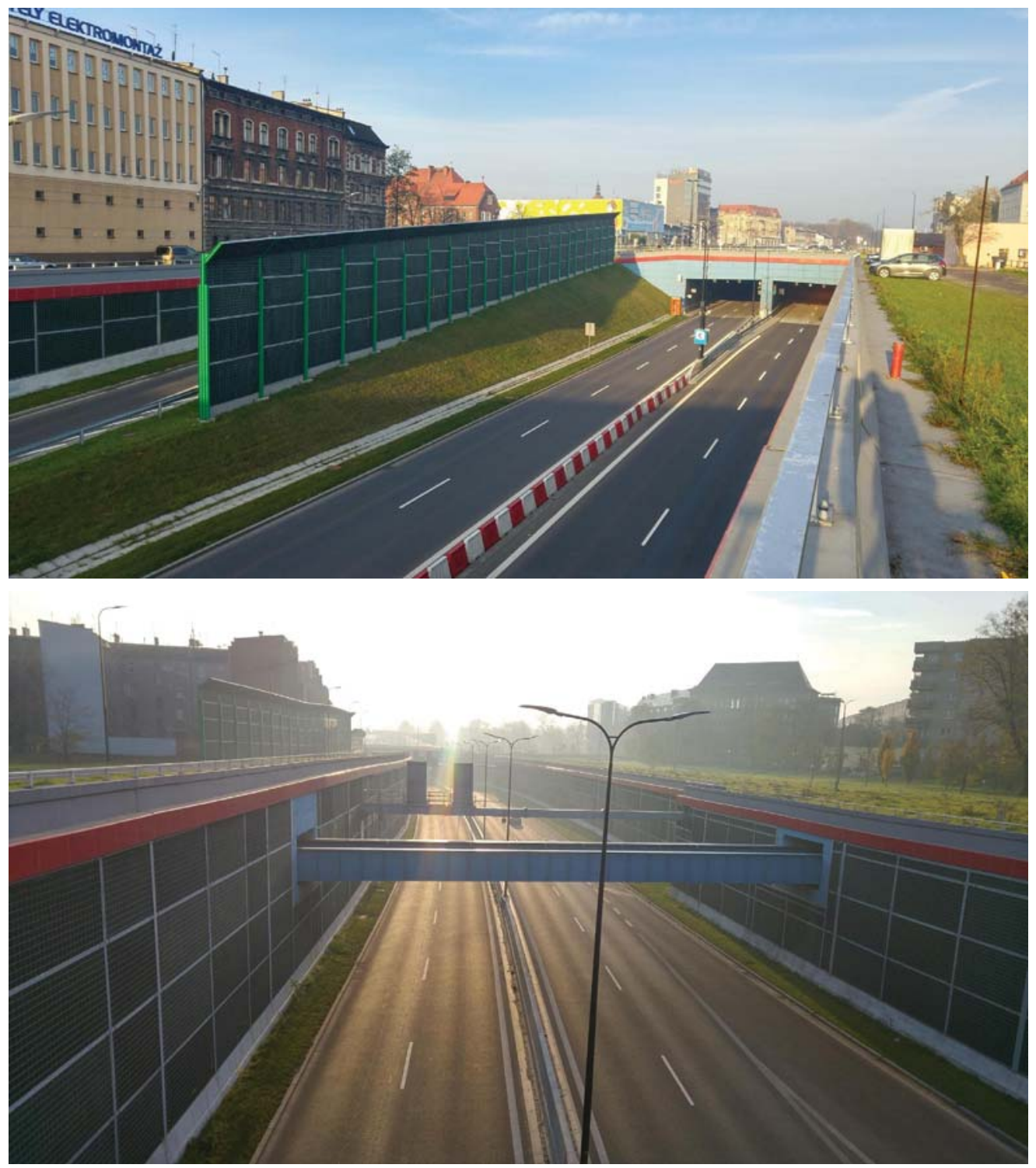

Fig. 2. "Concrete Cube 2015" anti-award went to the Cross-Regional Highway in Gliwice.

"For dividing the city" (photo by R. Blazy) 
drive this way every day. The central functions in Chorzów had to be taken over by Wolności street, modernised several years ago.

Currently, a very important reconstruction of the centre of Sosnowiec in the vicinity of 3 Maja street is planned. Several strategic investments have been planned along the road, such as a market square, which is to be built near the main railway station. The cost of one of the sections of the reconstruction is to reach more than PLN 60 million.

The period of the last 30 years connected with the multidimensional transformation of the Polish spatial reality results primarily from socio-political transformations and constitutes their consequence. Paradoxically, the contemporary capitalist economy cares more for making spaces pro-social than socialist authorities before. The social character of spatial solutions is one of the leading concepts accompanying the reconstruction of Polish cities over the last three decades. This pro-social approach aims to create spaces friendly for people due to their scale, interesting details, sometimes ornaments, friendly and ergonomic fittings. Street furniture catering for all sorts of human needs constitutes an essential component of reconstruction of the Polish urban space. Nevertheless, as it can be seen in Katowice, Gliwice, and Chorzów, if even less valuable development is removed, we are unable to perceive and evaluate contrasts existing between historic structures and their surroundings. Sometimes we are not even able to recognise entire former urban projects. These spaces start to play a completely different role in social terms, too. Frequently municipal authorities are not aware to what extent transformations of the urban tissue influence transformations of the life of the city.

It should be remembered that responsibility for the appearance of our towns and cities is not only borne by urban planners, investors, and decision makers, as when we look for relations between the law and the plan, we have to admit that it is the law that is the primary element deciding about the form the plans assume. It is the law that determines the rules governing plans. It is the law that allowed to build Place Stanislas in Nancy and the WZ route in Warsaw.

\section{Ideas implemented in contemporary silesian cities}

Ideas have always accompanied man. In most cases each of our actions is preceded by reflection. This reflection is connected with a vision which rises in us and which constitutes the initial motif in the process of creating spaces. In the case of space creation, it is a concept, an idea, the essence of the created or co-created intention. It is a seed which is the beginning of a plant, and in this case which provides the foundation for weaving a complicated structure of spatial links and functional - spatial - social relations. Each time a newly created urban tissue is grafted onto a certain concept. In principle, the contemporary Silesian solutions are based on the trend of postmodernist development concepts. In technical terms, they try to satisfy the requirements of sustainable development and economic effectiveness. Frank Lloyd Wright wrote that "ideas shape our reality". Admittedly, ideas are undoubtedly the keynote in many our actions. Sometimes they are built around a specific architectural or cultural trend, sometimes they constitute a collection of ideas and goals which a given author or investor wishes to accomplish. 
Contemporary revitalisations of Katowice, Gliwice, and Chorzów, although embedded in the existing urban tissue, do not inscribe into the concepts of contextualism, nor into the idea of a compact city. Continuing the thought cited, it should be stated that very often they do not refer with their assumptions in a clear and legible manner to the existing urban tissue. At the same time, the general concept is implemented predominantly by means of deconstructivist patterns and codes (Fig. 3), which quite often lead to spatial disintegration (development around the edifice of the Polish National Radio Symphony Orchestra, fragments of the revitalisation of the Market Square in Katowice, the building and development of the new railway station in Katowice, the solution of the Congress Centre near Spodek). Numerous publications, presenting deconstructivist visions, contribute to the popularity of this idea. A certain frequently observed feedback between the deconstructivist form of the urban plan and the lack of legibility and hierarchy in the spatial solution is quite conspicuous. The clash of the newly emerged urban tissue reveals different compositional concepts of the liberal architecture and neo-classical architecture.

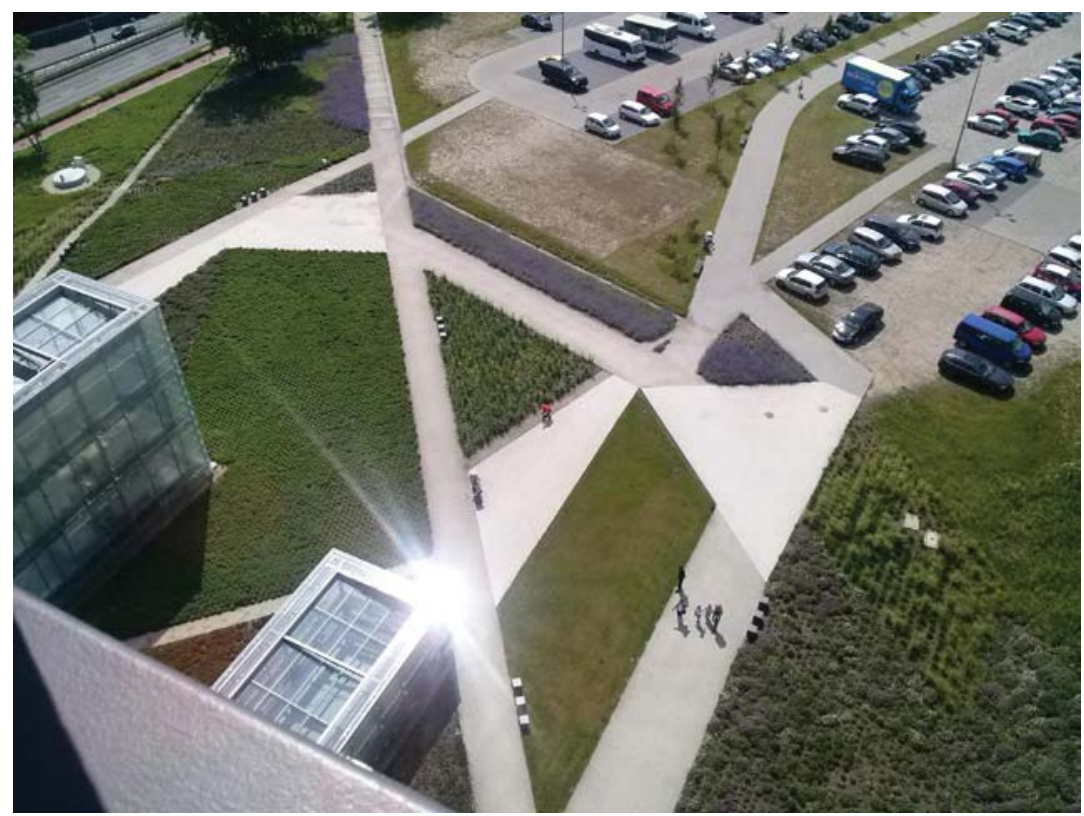

Fig. 3. Deconstructivist concepts of organisation of the public space division near the edifice of the Silesian Museum in Katowice (photo by R. Blazy)

The contemporary disintegration of urban areas in the Silesian agglomerations results also from e.g. transforming streets and roads into traffic routes characterised by high capacity and traffic intensity. Quite often different actions are undertaken in the name of transport development and improvement, which in fact are not oriented towards creating a coherent urban space. Large-scale commercial and office facilities erected along transport routes become examples of insular urban planning (KTW, Silesia Business Center, National Polish Radio Symphony Orchestra). The overlapping social disintegration only intensifies 
such phenomena. Frequently their users struggle with the lack of pedestrian access routes to individual functions. Regarding contemporary Silesian projects, it seems that transport functions develop at the expense of the loss of continuity of the spatial structure and at the expense of public functions (Fig. 2 and Fig. 4). The urban environment characterised by easy access for pedestrians, intensification of functions, human-friendly scale simply does not come into being at all. Two shopping centres should be regarded as exceptions from this rule in the Upper Silesian agglomerations: Forum in Gliwice, and Agora in Bytom.

Although according to many contemporary urban planners, in compliance with the transit oriented development principle (TOD) functions and development are to be intensified around transport hubs, still the practice and the reality of Silesian towns and cities demonstrates that - regrettably - such activities simply do not happen as far as designing the road system is concerned. ${ }^{4}$ And despite the fact that roads constitute an element on which the new development is actually based, they are not capable of acting as an element integrating the urban tissue themselves. Therefore, the approach focused on transport and traffic related goals is underlain by a wrong assumption as to their meaning in the life and functioning of cities. In the context of a purely scientific approach, the initial assumptions are wrong a priori. It needs to be acknowledged, however, that multimodal transport hubs and traffic junctions connected with efficiently functioning public transport can play such a role more effectively (Katowice, Gliwice railway station reconstruction project). Generating social, spatial, and economic benefits results largely from well and attractively designed public spaces, integrally bound with attractive functions of their envelopes.

A paradox of numerous linear elements in the city consists in the fact that they are perceived as elements which construct the city and deconstruct it at the same time. Undoubtedly, such elements include railways, roads, rivers, canals, and even uniform greenery belts. In this respect traffic routes and arteries constitute a big contemporary problem in Silesian cities. Without their intersections within the limits of the city or in its vicinity the life in the city would not exist at all, and the city would not be the space of exchange, as well as it would not be the destination of many travellers. The accessibility of the city would get reduced, too, and it is also its characteristic feature. The paradox, however, consists in the fact that at a certain stage traffic routes deconstruct the urban structure (examples of Katowice, Chorzów, Sosnowiec, Ruda Śląska, Zabrze). In this case the significance of transport leads to contradictory and inconsistent conclusions. Therefore, measures weakening the disintegrating role of transport seem to be extremely important. In the era of constantly growing volumes of public transport and cars moving around inner cities, this antinomy, or contradiction of the city's right to develop, will increase.

Maintaining the principles of continuity in space reduces the totalism of assumed forms and solutions. There occurs a certain feedback here, where continuity reduces totalism, and totalism interrupts continuity. Sometimes one has to set less ambitious aesthetic and designrelated goals and to implement projects and facilities more adjusted to psychomotor capacities of an ordinary human being. At the beginning of the $19^{\text {th }}$ century, Sebastian Sierakowski wrote: "For all centuries of greatness, the grandeur or shabbiness of a building was and is the measure

4 Numerous publications devoted to "transit oriented development" (TOD) are published on the website: [14]. 
of a magnificent or shabby mind" [13, p. 220]. The value of the preserved cultural heritage depends on the importance attached by the society to urban and architectural projects and to the process of shaping of the living environment, which each town and city is.

Good urban practice is more and more often mentioned in the Polish urban planning. Good practice is the practice that corresponds to human needs and possibilities. Unfortunately, everything that was destroyed in the last 70 years requires improvement and revitalisation. The role of an urban planner is extremely difficult in this respect. He is probably the only warden of spatial order in towns and cities.

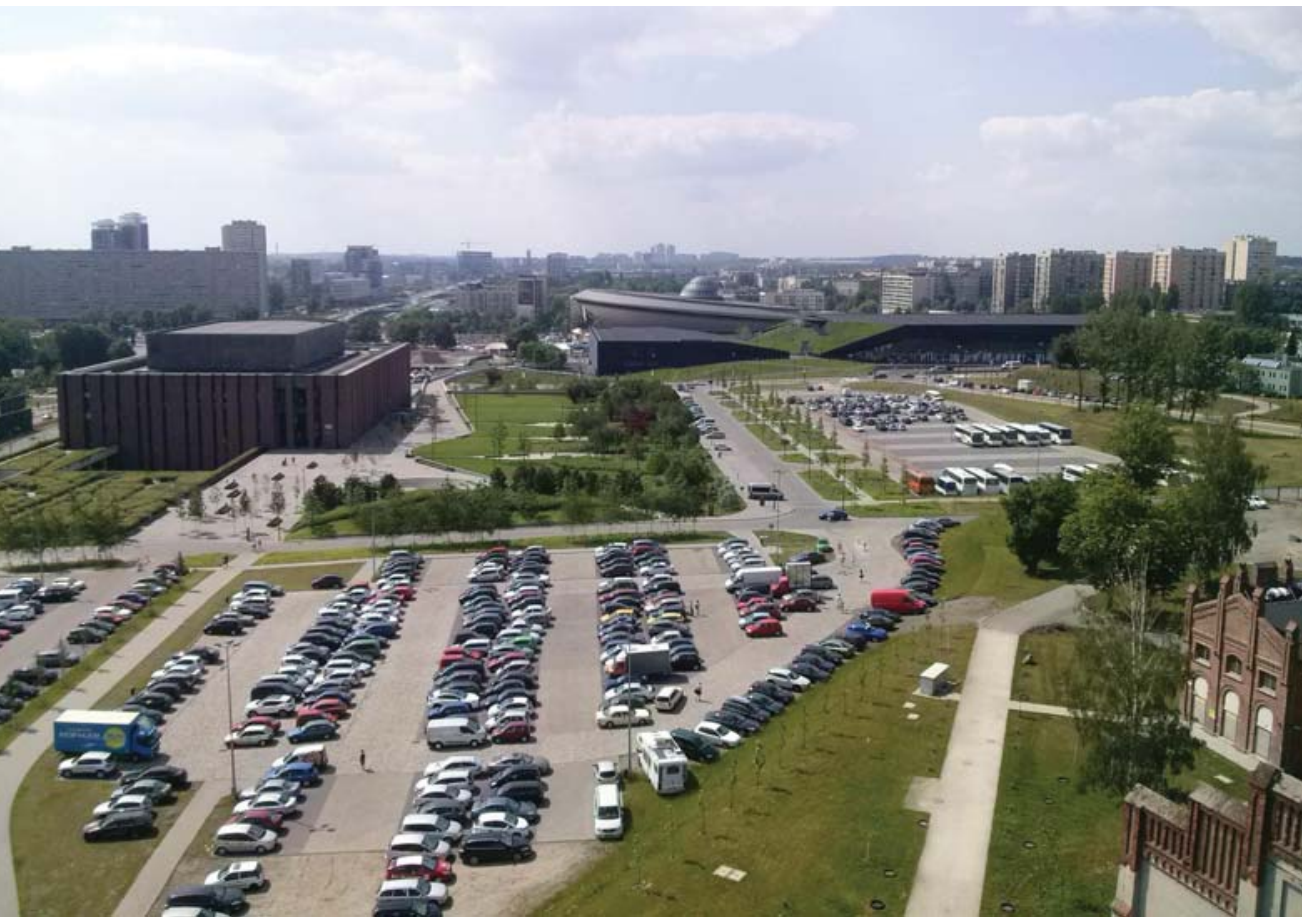

Fig. 4. Fragmented, mosaic-like space of the centre of Katowice (photo by R. Blazy)

\section{Effects of undertaken actions vs. Urban life}

L. Mumford noticed that what transforms a village into a town is not merely the population density, nor access to specific resources, but everything that broadens the territory of mutual relations, which gives rise to a need of complex social cooperation, communication, and communion [10, pp. 5-7]. A characteristic feature of historic cities was the fact that a large portion of the urban life took place in streets and public spaces. Streets bustling with life are nearly synonymous with the city and urbanity; hence designing streets not connected with the urban life weakens the attractiveness and vitality of the city.

Population dynamics in communes of the province of Silesia in years 1999-2012 demonstrate that the largest outflows of people take place in the most central area of the 
province and concern such communes as Katowice, Chorzów, Ruda Śląska, Zabrze, Piekary Śląskie, Świętochłowice, Gliwice, where a 5-10\% drop of the total population was observed - the highest drop in this respect was registered in Bytom - $10 \%$.

This is additionally strengthened by the migration of people from central areas of these cities to their suburbs. A considerable drop in this respect was recorded in Katowice. In the inner city of Katowice the number of permanent residents between 2008 and 2014 dropped nearly by $1 / 4$. At the same time, population density in the city centre dropped by ca. 1500 residents per square metre. Historically speaking, the area of the city centre used to be the most densely populated part of the city. Despite the fact that population density in the city centre is higher than in the areas adjacent to it (inner city districts), still their situation is much more stable as far as population is concerned. Studies confirm that a considerable drop in the number of permanent inhabitants of the inner city changes the way in which Katowice functions considerably.

Disintegration resulting from the drop in the population in city centres and downtown areas in Silesia consolidates negative effects of the new spatial organisation. Regress of palpable and non-abstract social relations has a very strong impact on the life of inner cities, as well as on the very physical form of cities. Weakening of physical relations between people, and even companies and other business entities, finds its reflection in the urban space. It is undoubtedly connected with the transfer of contacts, services and sales of goods to the virtual reality. The problem of human presence in the space of cities is not exclusively a transportrelated problem, but a cultural one. The policy implemented in Barcelona, Copenhagen, or Helsinki can be quite interesting in this respect. It is a spatial policy oriented predominantly towards pedestrian traffic. In Barcelona, under relevant regulations of the municipal authorities, hypermarkets can be situated only in places easily accessible for pedestrians.

It seems that in our reality it is a factor which is completely disregarded. Demographic data of Silesian cities prove that we are still in the phase of deglomeration of inner cities, and populations of inner cities constantly drop, whereas suburbs expand. The population curve presented on the diagram (Fig. 5) illustrates tendencies occurring within the inner city of Katowice. This study is important as it illustrates what developmental phase we are currently in and what we can expect in the near future. Today, despite numerous revitalisations, inner cities do not get activated, because activities are limited only to the sphere of trade, and only to a certain extent to entertainment and other services. Outflow of people inhabiting city centres, confirmed in studies carried out by K. Bierwiaczonek and T. Nawrocki, as well as strongly competitive activities of shopping centres towards traditional city centres, seem to be the most significant in this respect. The constantly growing number of commuters accounts for the fact that many people who stay in the inner city even periodically, still behave in an alienated way, like "resilient aliens".

The problem of functional transformations, necessary to be introduced in contemporary inner cities, is complex and multithreaded. Stopping the outflow of people inhabiting central districts seems to be essential in this respect. Municipal authorities should make efforts to constantly improve the attractiveness of the residential function in city centres and inner cities. This fact is firmly inscribed in the tradition of European cities, where city centres where inhabited by people from upper classes due to the accessibility of functions, as well as 

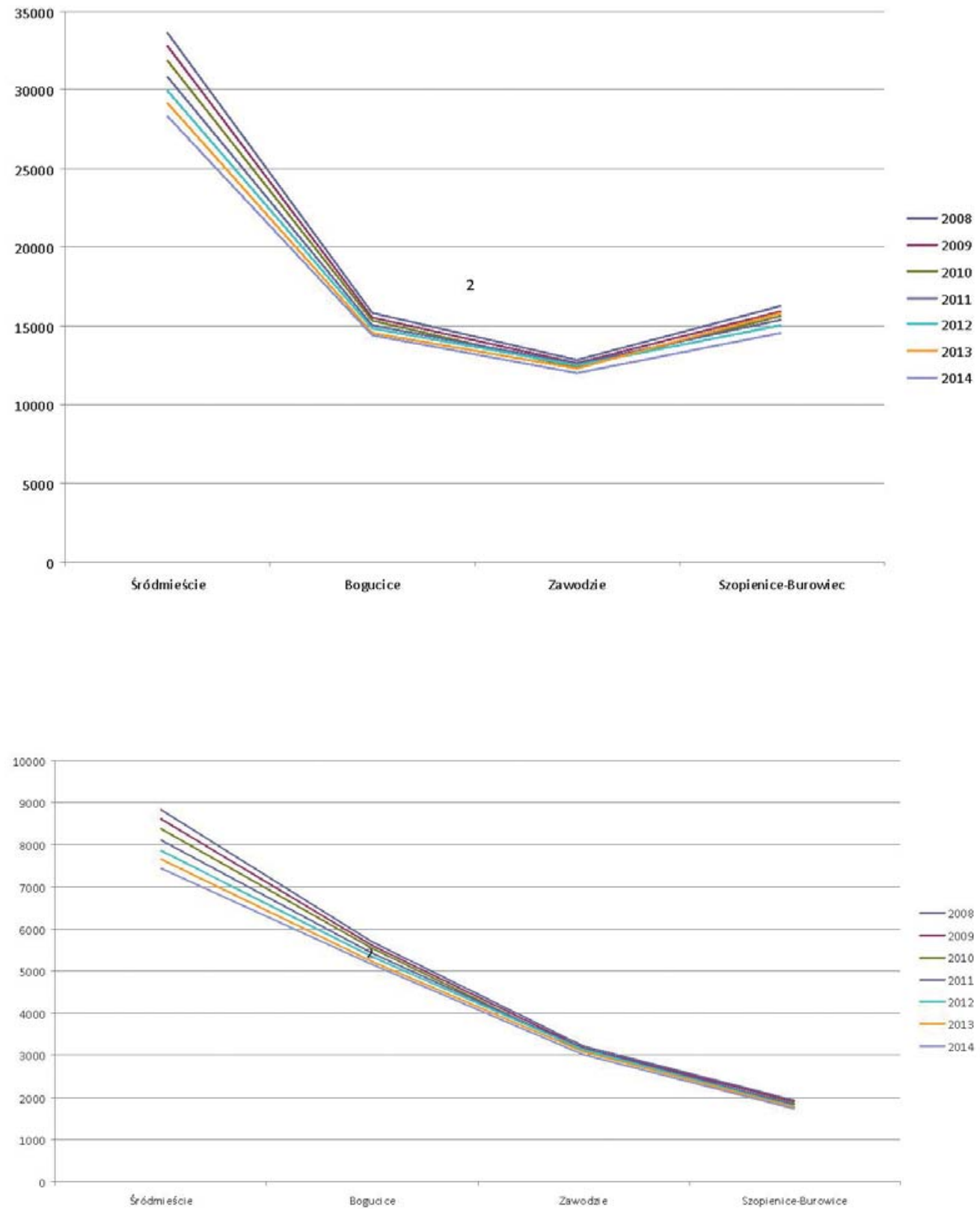

Fig. 5. Population and population density diagrams for selected central districts of Katowice (compiled by the Author on the basis of the data from the Katowice City Hall) 

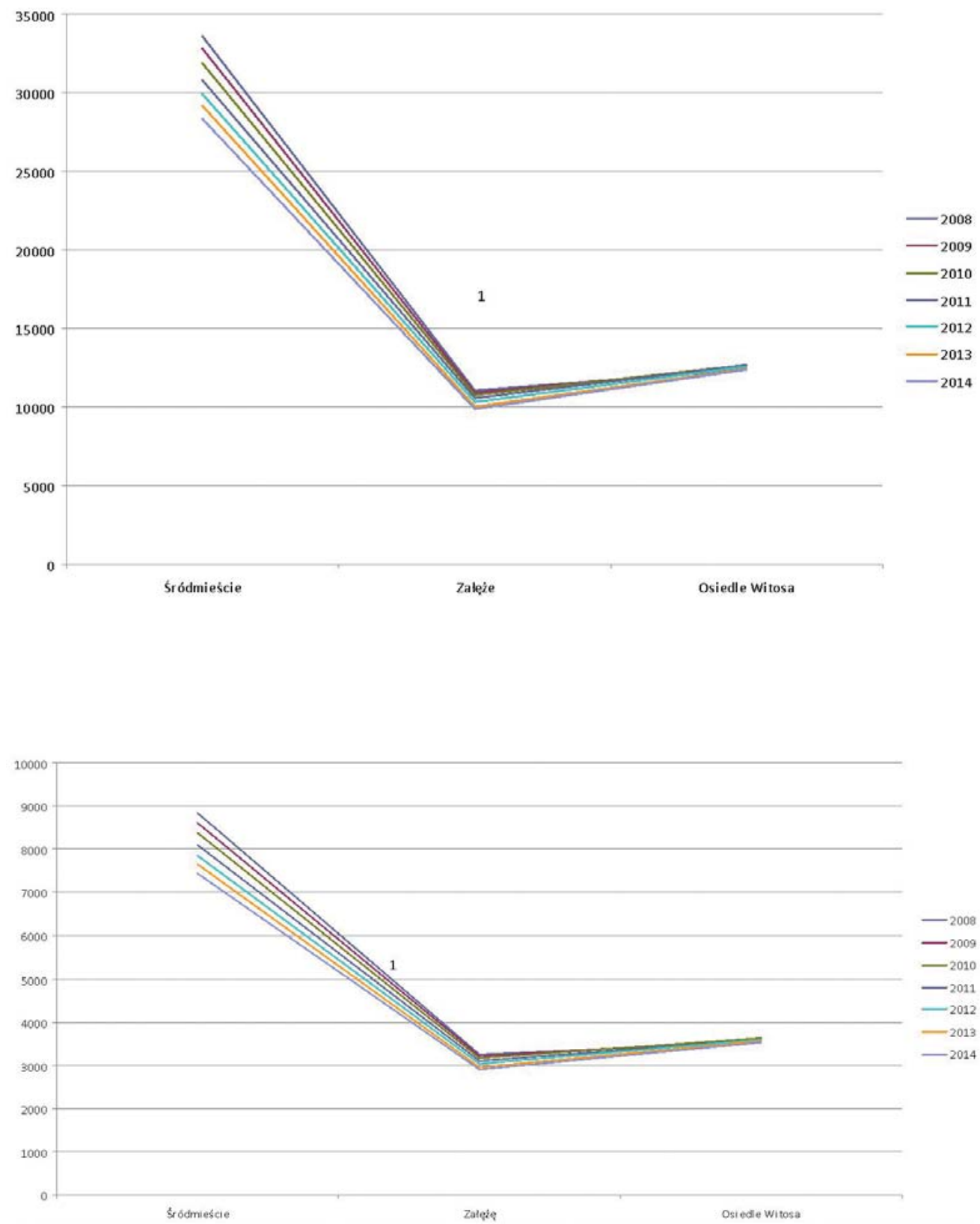

Cont. fig. 5. Population and population density diagrams for selected central districts of Katowice (compiled by the Author on the basis of the data from the Katowice City Hall) 
prestige. Thus in numerous city centres on the so-called old continent we will find magnificent palaces, villas, residences, and hotels, very different in terms of form - as single edifices, as city blocks, or even as entire urban projects. Hence balancing and strengthening of the residential function in areas dominated by services and commerce should become a valid principle. It is crucial that commercial or business monostructures are not allowed in the city.

According to the CityLab portal, which refers to American studies, there is a growth of the demand for apartments in American inner cities today. It is connected with the so-called reduced tolerance for commuting to work, observed in households with a high double income. People who earn well usually spend more time in offices, and at the same time they long for free time. As the time allocated to rest shrinks, central locations become incredibly valuable as easily accessible areas. This fact becomes more and more significant as a very important factor taken into account when choosing a place of residence. The study was conducted on 27 cases of densely populated cities in the USA, where the total of 65 thousand locations (research points) were selected, subjected to observations lasting 30 years since 1980 until 2010. During this time a growing tendency in terms of preferences to live in city centres among highly qualified staff was observed. Simultaneously, researchers observed that highly qualified work is most concentrated in the very heart of the city. City centres $(0-5 \mathrm{~km})$ were inhabited by three times more highly qualified workers than inner cities (5-15 km); suburbs, on the other hand, were inhabited by seven times fewer highly qualified workers than in inner cities $(15-30 \mathrm{~km})$. These observations indicate that there is a tendency amongst hard-working well-educated inhabitants to live close to the city centre. American studies demonstrate what can be the actual dominating driving force in the increase of the attractiveness of the city centre as the place of residence and life [15].

Many times over centuries we have observed that the life of cities, as well as the life of people, is subjected to fluctuations; hence we can expect that quite soon a similar tendency might occur in the most important Silesian cities. Therefore, certain measures should be undertaken to meet the expectations observed globally.

\section{Conclusions}

When we wander around old districts of cities and admire their form and development, we face a very disturbing question of what is our current contribution in the history of building cities compared to grand works of urban planning and historic architecture. How will the future generations evaluate the legacy left by us? What facilities and structures must come into being so that this evaluation could be a positive one? Frequently we tend to evaluate positively structures whose construction is connected not only with satisfying the needs of their contemporary residents, but most of all with visionary concepts of their creators, who made a great effort to achieve their goal.

Most often common thinking on improving a city is limited to its structure, law, regulations, and institutions responsible for the city. When we adopt a historical approach, i.e. when we consider measures which brought about actual qualitative changes in the city, most often 
they do not fall into the limits of the fixed legislative system, and therefore they required considerable efforts to be implemented. They did, however, bring very positive results, and very often became models for reconstructions of the urban structure.

The most important in this respect are changes in the social sphere relating to culture, ethics, mindset, and behaviour. They decide about the form of civilisation, its rhythms, and manifestations of life. Recognised individual models of life are decisive about the urban life. Human life cannot be regulated by regulations or structure, it cannot be done from the outside.

Space atomisation observed within the perimeter of Silesian cities takes place predominantly by means of free polarisation of priorities in spatial assumptions of new investments. Instead of compilation there occurs weakening, or even disintegration of existing functional links (example of Gliwice, Chorzów, and large areas of Katowice), which in turn contributes to the separation of the newly emerging function and form of development from the existing urban tissue, and eventually leads to erosion and fragmentation of the territory of the city.

At the end, it is worth quoting very accurate and important words of Barbara Bartkowicz:

One can and must $[\ldots]$ ask a question on the hierarchy of goals and the criteria of their selection. Irrespective of attitudes and differences of opinions of representatives of different fields of knowledge, the determinant and the superior criterion in the selection of goals and evaluation of actions should be human needs - not the current, present ones, but needs that are non-negotiable for maintaining humanity - physical and mental ones, which need to be satisfied in order to maintain good health and development of individuals as well as societies.

Without getting into details, it should be stated that deliberations of psychologists and sociologists point to the need to maintain balance in the selection of goals, as the primacy of e.g. economic or functional goals can jeopardise the ability to satisfy many other needs connected with the environment of human life (e.g. the need of peace, harmony, contact with nature, or sense of safety).

These premises of balance constitute the foundation for the general task of urban and spatial planning, which is creating harmonious spatial frameworks for comprehensive activities of individuals and societies in the pursuit of satisfying needs, self-actualisation, progress, and development. A confirmation, and at the same time formulation of this task is a broadly understood principle of sustainable development, underlying urban and spatial planning, which in the contemporary times have been defined in detail and adopted as applicable in all civilised parts of the world [1, pp. 9-10].

\section{References}

[1] Bartkowicz B., Cele i zasady w planowaniu przestrzennym i urbanistyce a projekty unijne $w$ Matopolsce, Czasopismo Techniczne, 15-A/2005, 9-10.

[2] Bartkowicz B., Ewolucja poglądów od strefy ochrony do równoważenia rozwoju struktury miejskiej ze szczególnym uwzględnieniem projektów dla Tarnowa, Czasopismo Techniczne, 7-A/2007, 21-34.

[3] Bartkowicz B., Problemy harmonizowania przestrzeni Polskich miast i obszarów w świetle wewnętrznych uwarunkowań oraz integracji z Unia Europejska, Czasopismo Techniczne 2-A/2005, 28-35.

[4] Bartkowicz B., Ustalenia planów zagospodarowania przestrzennego w świetle zmieniających się przepisów prawa a oczekiwania odbiorców, [in:] Skuteczność planów zagospodarowania przestrzennego potrzeby i możliwości, Kraków 2003. 
[5] Bierwiaczonek K., Nawrocki T., Centrum miasta czy mall? Kilka refleksji socjologów na marginesie badań przestrzeni publicznych miast śląskich, Górnośląskie Studia Socjologiczne, Seria Nowa 2, 213-231.

[6] Gasidło K., Kierunki przekształcen przestrzeni przemystu, Publishing House of the Silesian University of Technology, Monograph, Vol. 269, Gliwice 2010.

[7] Jałowiecki B., Człowiek w przestrzeni miasta, Katowice 1980.

[8] Jałowiecki B., Przestrzeńludyczna - nowe obszary metropolii, Studia Regionalne i Lokalne, No. 3(21), 2005.

[9] Jałowiecki B., Znaczenie przestrzeni, Studia Socjologiczne, No. 1/2, 1991.

[10] Mumford L., Miasto, Polis, No. 6, 1996.

[11] Nawrocki T., Miasto bez centrum? Centrum Katowic w oczach mieszkańców, [in:] Przemiany miasta. Wokót socjologii Aleksandra Wallisa, ed. B. Jałowiecki, A. Majer, M.S. Szczepański, Scholar, Warszawa 2005.

[12] Nawrocki T., Koszmarny sen. Centrum przemystowych Katowic w oczach mieszkańców, Przegląd Socjologiczny, Vol. 57, No. 1, 2008, 249-269.

[13] Sierakowski S., Architektura obejmujaca wszelki gatunek murowania $i$ budowania, Drukarnia Akademicka, Vol. 1, Kraków 1812.

[14] http://www.nlc.org/program-initiative/sustainable-cities-institute/topics/land-useand-planning/transit-oriented-development-(tod) (access: 31.01.2018).

[15] https://www.citylab.com/transportation/2015/11/why-the-wealthy-have-beenreturning-to-the-city-center/416397 (access: 31.01.2018).

[16] http://www.mck.katowice.eu (access: 31.01.2018).

[17] http://www.nospr.org.pl/pl/o-projekcie (access: 31.01.2018).

[18] http://www.urbanity.pl/slaskie/katowice (access: 31.01.2018).

[19] http://katowice.wyborcza.pl/katowice/1,35063,13517913,7_03_2000_r Centrum_Sosnowca_czyli_jeden_wielki.html (access: 31.01.2018).

[20] http://www.nowiny.gliwice.pl/centrum-przesiadkowe-w-gliwicach-ma-powstac-zatrzy-lata (access: 31.01 .2018 ). 


\section{ADDENDUM}

Examples of big investments relating to reconstructions of Silesian city centres.

International Conference Centre (near Spodek)

Implementation: since 2011 until March 2015.

Total value of the project: PLN 378 million [16]

National Polish Radio Symphony Orchestra Katowice

Implementation: December 2010-October 2014

Total cost: PLN 305 million [17]

\section{Silesia Business Park}

Commencement - June 2013

Completion - September 2018 [18]

\section{KTW Katowice}

Commencement - June 2016

Completion - June 2018 [18]

\section{Silesia Shopping Centre}

Commencement - 2004

Completion - November 2005

Reconstruction 1 - September 2010-2011 [18]

Katowice Railway Station and Gallery: Integrated Transport - Commerce - Office

Centre

Commencement -2010

Completion - 2014

Total cost of the project is estimated at PLN 1056 million [18]

\section{Agora Bytom}

Commencement - March 2009

Completion - November 2010

Total value of the investment is PLN 186 million [18]

Reconstruction of the city centre of Sosnowiec 2002

Reconstruction in 2002 comprised the railway station and Stulecia square

Railway station - 1997-2002

The renovation of the railway station cost PLN 26 million [18]

Stulecia square - PLN 95 million [19] 
Gliwice Transport Hub. Designed by An Archi Group

Commencement - autumn 2018

Completion - 2020

Cost of the investment ca. PLN 150 million [20] 